\author{
A. S. SYNYTSIA ${ }^{1 *}$ \\ 1*Ivan Franko National University of Lviv (Lviv, Ukraine), e-mail andrii.synytsia.edu@gmail.com, \\ ORCID 0000-0002-0983-7187
}

\title{
ANTHROPOLOGICAL DIMENSIONS OF PRAGMATISM AND PERSPECTIVES OF SOCIO-HUMANITARIAN REDESCRIPTION OF ANALYTIC METHODOLOGY
}

Purpose. The paper is aimed at studying the specificity of anthropological problematics in pragmatism from the perspective of its ability to be the source of analytic philosophy evolution in the socio-humanitarian direction. Theoretical basis of the research is determined by the works of the representatives of classical pragmatism (C. S. Peirce, W. James, J. Dewey, F. Schiller), neopragmatism (W. V. O. Quine), post-pragmatism (R. Rorty) and analytic pragmatism (R. Brandom). Their works give a clear understanding of the important place of anthropological searches in the theory of pragmatism. Originality. On the basis of the analysis of logical, epistemological and metaphysical ideas formulated by representatives of pragmatism, it is proved that pragmatic methodology is anthropocentric. It is established that the ideological and social foundations of pragmatism can be determined as pluralistic ones due to the attention to the human person. It is revealed that theoretical and methodological searches of pragmatism can be effective in the formation of the socio-humanitarian concepts in analytic philosophy through the specification of strategies for the cognition of human existence in such terms as experience or self and the development of practical ways to justify the truth of knowledge. Conclusions. Pragmatists criticized impersonal, formal thinking, which cannot be an effective means of cognition. Thinking has a social basis and is entirely personal. Justifying its dependence on the socio-cultural sphere and the internal intentions of the subject, it is possible to develop an effective logical theory that operates symbols not only at the syntactic or semantic level but also takes into account the pragmatic aspect of language. Anthropological problematics is also important in the theory of knowledge, the core of which is the notion of pragmatic belief, which enables truth and religious beliefs, since the foundation of the theory of truth is determined by the principle of humanism, and the truth is interpreted as a value orientation. Knowing the external world, we find in it the similarity with us - that's why the metaphysical foundations of being, according to pragmatism, are personified, and the methodology is defined in anthropomorphic terms. Applying it, the study of human existence is specified in the analysis of psychological and socio-cultural dimensions of such concepts as experience or self. Attempts to comprehend the nature of human existence in pragmatism are empirically grounded. Appealing to science, methodological pluralism, the search for socio-cultural background for thinking and suitable linguistic forms of expression of human experience are the achievements of pragmatism, which are the basis for the socio-humanitarian redescription of analytic methodology.

Keywords: anthropology; anthropomorphism; principle of humanism; experience; self; pragmatism; analytic philosophy

\section{Introduction}

The interaction between the representatives of analytic philosophy and pragmatism assumed special prominence in the first half of the twentieth century. At first, it dealt mainly with problems of mathematical logic (such as the C. S. Peirce's rejection of certain logical provisions from "Principia Mathematica" of B. Russell and A. N. Whitehead), critique of W. James's pragmatic theory of truth from the side of B. Russell and G. E. Moore. Later - in the middle of the twentieth century W. V. O. Quine, D. Davidson synthesized the ideas of both directions in the form of neopragmatism, which opened up the possibility for the formation of ideas of metaphysics and critique of empiricism in analytic philosophy and radically changed its initial principles. Such distinctions existing in the pragmatism as knowledge by acquaintance and knowledge by description, types and tokens, etc. have become the components of analytic 
philosophy. R. Rorty developed the foundations of the philosophy for post-pragmatism by adding the ideas of neo-pragmatism with postmodernism. This kind of innovations contributed to the redescription of analytic methodology in the context of socio and anthropological issues of philosophical discourse. However, this process was not fully understood in its origins and theoretical objectives. Therefore, with the growing interest of anthropological problematics in analytic philosophy, it is important to find out how the corresponding pragmatism experience in its classical and contemporary interpretations is useful for further progress in this direction.

This topic has been poorly studied in the scientific literature, although some of its theoretical and methodological aspects have recently been drawn to the attention of some researchers, including C. Misak (2015), who investigated the influence of American thinkers C. Wright, C. S. Peirce, W. James, J. Dewey, and W. V. O. Quine on logical empiricism and related issues; A. Boncompagni (2016), who analyzed the concept of doubt, certainty, common sense, forms of life, actions existing in L. Wittgenstein's philosophy which are not devoid of a pragmatic dimension; F. Bellucci (2017), who clearly demonstrated the importance of C. S. Peirce's pragmatic ideas for the analytic philosophy of language; J. Carroll (2018), who in the process of studying the anthropological premises of W. James's philosophy, grounded the prospects of new interpretations of his ideas through the prism of a number of important concepts in the analyticophilosophical discourse (such as experience), as well as authors of the collection: "Pragmatism and the European Traditions: Encounters with Analytic Philosophy and Phenomenology before the Great Divide" (Baghramian, \& Marchetti, 2018), which, in particular, explores the mutual influences, commonalities and distinctions of these three philosophical traditions and their influence on contemporary philosophical thought.

\section{Purpose}

To find out how anthropological searches for supporters of pragmatic methodology have proven to be an effective means for the development of analytic philosophy in the sociohumanitarian sphere.

\section{Statement of basic materials}

In order to achieve this purpose it is important to identify the anthropological specificity in the theory of pragmatism in the fields of logic, epistemology and metaphysics, as well as separately by the experience of the human personality and the person himself and to demonstrate its usefulness for the progress of analytic philosophy.

The humanistic basis of logic. The specificity of analytic philosophy is defined by special attention to the logical accuracy in the formulation of thoughts. But what are the basics of logic? The answer to this question is given by pragmatist theorists. In particular, J. Dewey (1920), sharing the opinion that the structure of thinking corresponds to the structure of the status of affairs in reality, naturally emphasizes the empirical character of logic, although it clearly points out that the central concept of logic is judgment - "is not logical at all, but personal and psychological" (p. 133). Reference to the personal components of logical thinking makes logic an effective practical means of understanding reality.

In this connection, F. Schiller even reformed traditional logic, proposing to replace it with a humanistic logic that 
...challenges all the earlier logics, and accuses them of a false and inade-

quate analysis of knowing, due to a false and foolish intellectualism,

which has ignored and abstracted from all the characteristic operations of

real thinking, and substituted a whole system of fictitious notions and ab-

stractions. (Schiller, 1938, p. 16)

Such logic would not be overly abstract, disconnected from the process of cognition, and would not resemble manipulation of symbols, which has nothing in common with active thinking inherent in a man. On the contrary, humanistic logic emphasizes the interrelationship with psychology and does not seek to substitute truth with formal correctness, since it aims at finding true premises and conclusions, which is not possible only in the process of symbols manipulation.

It is noteworthy that the founder of pragmatism, C. S. Pierce, considered the preconditions of logic not only in a personalistic way but also pointed to its socio-anthropological implications. He wrote: "Logic is rooted in the social principle. To be logical men should not be selfish" (Peirce, 1878, p. 611). Therefore, the way people think is determined by the characteristics of coexistence and communication according to the norms of morality. Therefore, in order to define more clearly the logical foundations of analytic methodology, it is important to pay attention to the socio-cultural determinants of thinking and, in general, the logical specificity in the studying the nature of social being and a person him/herself. Semiotic interpretation of logic suggested by C. S. Peirce would be useful, it is based on the understanding of the sign per se, which is closely related to the interpreter and does not exist by itself. In addition, certain types of signs, such as qualifications, express the subjective experience of a man and serve as a means of finding the semiotic equivalents of social reality, each subject in which, from the point of view of semiotic anthropology, becomes a symbol that defines the context of verbal discourse.

It can be argued that the ideas of C. S. Peirce's semiotics influenced the formation of KarlOtto Appel's transcendental pragmatics, for which it was important to demonstrate the subject's personality in the process of language signs analyzing. The subjective aspect of language is expressed in the concepts of experience, life world, language, and so on. And the attempt to combine intellectual and moral principles was further developed in the context of the studies of the analytical and philosophical schools in the second half of the XX - beginning the XXI centuries, who developed "human forms" of realism, in particular, the history of ideas (A. C. MacIntyre), the narrative philosophy of history (A. Danto, F. Ankersmith) and internal realism (N. Goodman, H. Putnam).

Anthropological aspects in the theory of cognition. In the context of the pragmatic theory of knowledge anthropological problematics is equally important than in logic. Therefore, it is natural that according to $\mathrm{C}$. S. Peirce the core of knowledge is the concept of pragmatic faith the defining basis for action. He specified his intentions as follows: "A belief which will not be acted on ceases to be a belief" (Peirce, 1966, p. 217). It makes actions systematic and conscious. The state of faith is the opposite of the mental state of doubt, which a person seeks to get rid of as quickly as possible, because it hinders movements, generates anxiety and discontent. Faith, on 
the contrary, brings peace and satisfaction. The process of finding it is expedient to interpret as a kind of research, which ceases as soon as the state of faith is reached. In connection with such a cognitive interpretation of epistemology, D. Snitko (2017) notes that: "The will to faith arises as the will to truth" (p. 117). The fact is that, when cognizing unknown things, they seek to overcome doubt and reach a state of faith (belief). And even though the scientific method will be most convincing to reach this state, other methods (stubbornness, authority or a priori), as one might conclude, will also be appropriate in the uncertainty conditions. All these methods only show that the process of cognizing is finding similarities with us. We could hardly have known the world if there weren't anything similar to the human mind in it, which determines our inherent anthropomorphic metaphysics. Therefore, it is human to describe the laws of nature with anthropomorphic terms. And the more these terms are anthropomorphic, the truer they are.

Human cognition is so anthropocentric that it even gave W. James (1911) the reason to define philosophy as "man thinking, thinking about generalities rather than about particulars" (p. 15). In other words, to understand the complex of knowledge acquired by a person of the objective world as a part of expressing his internal cognitive intentions. Like F. Schiller, cognition always stands for personal aspirations, and the truth is a humanistic value. Moreover, seeing in logic the result of human needs as a means of knowing the truth, which in its axiological basis corresponds to ethics and aesthetics, F. Schiller affirmed that:

Pragmatism will seem a special application of Humanism to the theory of

knowledge. But Humanism will seem more universal. It will seem to be

possessed of a method which is applicable universally to ethics, to aes-

thetics, to metaphysics, to theology, to every concern of man, as well as

to the theory of knowledge. (Schiller, 1907, p. 16)

Of course, understanding the intentions of pragmatism as epistemological ones is F. Schiller's own interpretation. As it was shown by the creative searches of J. Dewey in the field of educational philosophy, W. V. O. Quine in ontology, R. Rorty in social and political philosophy, the methodology of pragmatism is more universal. After all, the analysis itself as a method of cognition is essentially pragmatic, since it is based on the structuring the personal experience of subjects, determined by the presence of faith.

That is why it is no coincidence that from the standpoint of pragmatism, faith as a necessary component of the human personality can itself include its own confirmation. It has a psychological nature, and in general, it is human nature to show a will to faith, creating our own picture of the world. This idea was further developed by the analytic pragmatist R. Brandom, convincing us that our ideas about the world depend on the way we see. In other words, "knowledge-how" depends on "knowledge-that" (Brandom, 2011, p. 47). Each time, asking new intentions, according to which gaining knowledge about the world is simply impossible. There are certain theoretical bounds to the practical conclusions that can be deduced from our beliefs. For this, it is important to study not formal languages, but natural language - moreover, the context of its application should be determined from the point of view of culture, social causation, and its dynamic pragmatic, and not static, the semantic dimension should be taken into 
account. In such circumstances, language is a normative formation and socio-cultural practice, and the truth of knowledge is grounded on the principle of humanism, according to which the definable truths are created by a man.

However, it is important to understand that, despite subjectivism, the common biological basis of psychological processes becomes the key to building approximately similar foundations of sociocultural phenomena and understanding in communication. It is this moment, which had flashed in the W. V. O. Quine's theory of uncertainty of translation, become important in the analytic philosophy of mind. Indeed, paying attention only to the semantic features of linguistic meanings, it is difficult to find the criteria for their unambiguous interpretation and correctly understand what exactly is the determining stimulus to designate a specific object with an appropriate word, as in the case of the term "gavagai" (Quine, 1960, p. 29). With the naming of abstractions, the situation seems even more complicated. Limiting ourselves solely with the study of linguistic meanings following W. V. O. Quine, we can conclude that understanding is impossible not only between speakers of different languages but also within the same linguistic community because the meanings that communicators put into the same words can vary significantly. In pragmatism, on the contrary, the possibility of finding criteria for understanding between people is emphasized. The basis for this is the common psychophysiological basis of the human personality (self).

Anthropomorphic foundations of metaphysics. "The pragmatic method, - as W. James (2014) understands it, - is primarily a method of settling metaphysical disputes that otherwise might be interminable" (p. 21). Pragmatizing the metaphysical problem, the scientist makes the abstract theory more flexible and open to criticism. Interpreting the truth as good for the subject of a certain belief system, a question suggests itself about the nature of metaphysical knowledge. It is answered by C. S. Pierce, who builds scientific metaphysics on an empirical basis. His metaphysics is personified and, as a consequence, the theoretical basis of the methodology of pragmatism is to some extent anthropomorphic. This is evidenced by the presence of some research hypotheses each time as a result of a person's intuitive sense in the correctness of truth formed in the process of evolution. A man has a set of ideas that objectively reflect reality and enable him to understand the nature of reality. C. S. Pierce (1934a) notes: "Certain uniformities, that is to say, certain general ideas of action, prevail throughout the universe, and the reasoning mind is [it]self a product of this universe. These same laws are thus, by logical necessity, incorporated in his own being" (p. 421). However, this does not mean that C. S. Pierce focuses exclusively on biological aspects of thinking and neglects social ones, in the context of which truth is interpreted as a product of collective cognition on the basis of the scientific method.

W. V. O. Quine returns to the topic of metaphysics with a new force, transferring it from pragmatism to the sphere of analytic philosophy. Applying a pragmatic methodology, he considered it quite justifiable to analyze not only empirical but also metaphysical knowledge. Especially if they are important for understanding the essential core of the scientific theory, set of propositions of which cannot be the result of fixing empirical experience (Quine, 1951). The questions of truth and existence go beyond the logic of language; any attempts to define universals or explore abstract objects of science, the nature of causality, the correlation of possibility and necessity are ineffective if one focuses only on the study of empirical facts. As a result of comprehending the specificity of these questions in analytic philosophy, a metaphysical turn took place, which made it possible to apply the analytic methodology in the field of anthropology, whose questions are as ambiguous and complex as those of metaphysics (Synytsia, 2017, p. 117). 
The theory of experience. By means of analytic methodology, one concretized the cognitive strategies and conceptual foundations of the research. W. James and J. Dewey did similarly, who, in order to understand the nature of human beings, built a theory of pragmatism on the basis of the analysis of experience as dynamic one in essence. The first of them thinks that anthropological ideas, first of all, have the psychological background, the second - socio-cultural one. W. James (1911) is convinced that knowledge is gained empirically: "the tendency known in philosophy as empiricism, becomes confirmed" (p. 98). Therefore, the most reliable knowledge of the world, which most deeply characterizes its nature, can only be found in sensory experience (radical empiricism). By analyzing the senses (percepts) that mold the experience, a person is able to understand more deeply the essence of one's self and comprehend the nature of those concepts that form the conceptual framework of consciousness (we are talking about the concept of space, time, reason, substance, etc.). It is a convenient tool for the discursive cognition of the surrounding reality since concepts as such define the foundations of practical activity on a daily basis and form a system of values - the life guidelines of the individual. Due to their pluralism, social changes are possible in our world.

In J. Dewey's theory of pragmatism, experience determines the whole essence of human life. It is based on two inseparable principles - continuity and interaction. According to the first of them, "every experience both takes up something from those which have gone before and modifies in some way the quality of those which come after" (Dewey, 2015, p. 35). In other words, the new information does not become autonomous but interconnects with the existing information. According to the second principle, "experience is truly experience only when objective conditions are subordinated to what goes on within the individuals having the experience" (Dewey, 2015, p. 41). As a result of the interaction between the subject and the object, the boundaries between them become conditional. As consequence, the experience begins to be dependent on the situation, and its interpretation - on the aspirations and intentions of the subject, who uses thinking as a practical tool (hence and instrumentalism) to transform the world and construct his/her own personality. Since, according to the logic of J. Dewey, the activity of the subject is most clearly manifested in the process of social relations, so the concept of culture plays an important role in its constitution. L. Goldman (2012) even remarks: «Towards the end of his long life, John Dewey dropped the philosophical language of "experience" in favor of the anthropological language of "culture"» (p. 1). Culture becomes the ontological background that determines the conditions of learning and the boundaries of personal knowledge.

However, the concept of experience as a theoretical construct in itself is not an effective means for systematizing the results of cognition, since it is difficult to determine what epistemological properties it possesses (if it has at all) and whether they are exceptionally unique. Therefore, it is important for W. James and J. Dewey to associate the predicate of truth with experience rather than with language. In this regard, R. Rorty (1998) wrote: "Dewey's and James's attempts to give a "more concrete", more holistic and less dualism-ridden account of experience would have been unnecessary if they had not tried to make "true" a predicate of experiences and had instead let it be a predicate of sentences" (p. 298). Although, it is the analysis of linguistic expressions that can bring us closer to a correct understanding of the information recorded in the experience. That's why R. Rorty, putting pragmatism into better shape attempts to replace the concept of experience with the concept of language, which is the means of its expression. In this case, personal experience can be transmitted and analyzed intersubjectively, and others will serve as the basis for some beliefs, expressed by linguistic means. 
Human interpretation. Of course, the analysis of human experience does not replace the philosophical analysis of a human, the nature of which the representatives of pragmatism interpreted something similar. So C. S. Pierce understands a human as a social animal, who in the upbringing acquires the ability to harmonize his/her behavior in accordance with the rules of morality. The main motivators for his/her actions are moral-volitional efforts and faith, which seeks to establish a habit that a person will adhere to in the future. "A man is a bundle of habits" (Peirce, 1934b, p. 151), - summed up C. S. Pierce. These habits are formed throughout the lifetime and permanently affect our behavior. Although they can be considered a little more broadly - in the ontological aspect - as certain regularities (regularities in actions, functioning, changes), are inherent not only to us but also to all natural things, over which a person rises through thinking. In addition, as W. James (1890) argued, the importance of habits in society is difficult to overestimate, because they are "its more precious conservative agent" (p. 121). It is the habits that keep people from changing their daily routine or established lifestyle, which is more likely to do harm than good. However, by making the effort, the habit can be changed, because, as J. Dewey (2015) points out, it is a dynamic entity that is constantly evolving, albeit it is imperceptible (p.35). This is a process of acquiring new habits and a significant transformation (or even elimination) of previous ones, which makes this process an important element of cognitive activity (learning).

However, in order to understand the nature of a man, it is important not only to analyze the preconditions of his social behavior but also to comprehensively explore the psychological foundations of self. This is exactly what James (1890) did, convinced that the self consists of a constituent (material, social, spiritual and pure selves), feelings and emotions they arouse, as well as the actions to which they prompt (Self-seeking and Self-preservation) (p. 292). The material Self is defined by the objects that construct our everyday world. The social Self is the recognition of us by other members in the society and their individual attitudes for us (approving or condemning), which leads to its multiplicity. The spiritual Self is the set of states in consciousness, cognitive abilities, and properties forming the inner world of a person. Without them, only the pure Ego is left - the basis of cognition and temporal unity of a personality, which, however, is not a substance, and therefore cannot be empirically investigated. Moreover, since the flow of sensations is permanent, the self changes every time in its sensory dimensions. But the fundamentals of the human personality formed historically in a particular sociocultural environment, cannot be instantly or radically changed without changing the external and internal (in particular, cognitive) conditions that determine its behavior.

In general, as J. Carroll (2018) argues, in many respects, W. James's reasoning largely follows the concept of the anthropology of the 18th century. Of course, supplementing them with conclusions consistent with scientific and cultural theories of that time. Consideration of the process of cognition as a continual subject-object structure, interest in the concept of experience, moderate skepticism are characteristic of epistemological concepts in analytic philosophy. Therefore, they could well be applied and significantly supplemented in the process of anthropological research in the future, for which from the standpoint of pragmatism the process of socio-humanitarian redescription of the analytic methodology is important.

\section{Originality}

A systematic study of anthropological problematics in pragmatism is proposed and its effectiveness for the redescription of the ideas in analytic philosophy in the socio-humanitarian 
sphere is justified. It is proved that only understanding of the person as the goals and basis of philosophical cognition can become an effective pragmatic means of the relevant transformation of analytic methodology.

\section{Conclusions}

So, as representatives of pragmatism have demonstrated, any theoretical and methodological search is personalized, based on the principles of pluralism and practical usefulness, and focused on overcoming skepticism. The personal factor determines foundations of logic, epistemology, and metaphysics. Knowledge cannot be impersonal, as it is a response to the cognitive needs of the subject. Their meaning is defined by our intentions, needs and prior experience. The principles of functioning in our thinking are consistent with the patterns of social existence. Therefore, cognitive truths become values that serve as guidelines in the world. Since the existence of each person is unique, it is precisely the pluralistic approach to studying his spiritual world that allows us to conduct a well-considered analysis. The problem of language plays an important role in this analysis. Terms like experience, self or mental record individual characteristics of human beings that require clear semantic-pragmatic forms of expression. Human research according to the methodology of pragmatism is grounded on a number of empirical and theoretical results in psychology, biology, cognitive science, sociology, cultural studies, etc. It is the achievements of these sciences that form the primary foundation of anthropological research in analytic philosophy. The experience of pragmatism demonstrates that the determining basis of sociohumanitarian redescription of the analytic methodology is determined by the need to revise the logico-epistemological concepts of analytic thinkers and the requirement to rethink depersonalized relativistic ideas that form the basis of analytic metaphysics. This contributes to the formation of the semantic-pragmatic basis for anthropology as an independent line of analytico-philosophical research, through which the foundations of human's spiritual being are reconstructed.

\section{REFERENCES}

Baghramian, M., \& Marchetti, S. (Eds.). (2018). Pragmatism and the European Traditions: Encounters with Analytic Philosophy and Phenomenology before the Great Divide. Routledge. (in English)

Bellucci, F. (2017). Peirce's Speculative Grammar: Logic as Semiotics. Routledge. (in English)

Boncompagni, A. (2016). Wittgenstein and Pragmatism. London: Palgrave Macmillan. (in English)

Brandom, R. (2011). Perspectives on Pragmatism: Classical, Recent, and Contemporary. Harvard University Press. (in English)

Carroll, J. (2018). William James and 18th-century anthropology: Holism, scepticism and the doctrine of experience. History of the Human Sciences, 31(3), 3-20. doi: https://doi.org/10.1177/0952695118764060 (in English)

Dewey, J. (1920). Reconstruction in philosophy. New York: Henry Holt and Company. (in English)

Dewey, J. (2015). Experience and Education. New York: Free Press. (in English)

Goldman, L. (2012). Dewey’s Pragmatism from an Anthropological Point of View. Transactions of the Charles S. Peirce Society, 48(1), 1-30. doi: https://doi.org/10.2979/trancharpeirsoc.48.1.1 (in English)

James, W. (1890). The Principles of Psychology: In two volumes (Vol. 1). New York: Henry Holt and Company. (in English)

James, W. (1911). Some Problems of Philosophy: A Beginning of an Introduction to Philosophy. London: Longmans, Green. (in English)

James, W. (2014). Pragmatism: A New Name for Some Old Ways of Thinking. Cambridge University Press. (in English) 
Misak, C. (2015). Pragmatism and Analytic Philosophy. In M. Beaney (Ed.), The Oxford Handbook of The History of Analytic Philosophy (pp. 1098-1117). Oxford University Press. (in English)

Peirce, C. S. (1878). The Doctrine of Chances. The Popular Science Monthly, 12, 604-615. (in English)

Peirce, C. S. (1934a). On Selecting Hypotheses. In C. Hartshorne \& P. Weiss (Eds.), Collected Papers of Charles Sanders Peirce: Vol. V and VI: Pragmatism and Pragmaticism and Scientific Metaphysics (Vol. 5, pp. 413-422). Cambridge: The Belknap Press of Harvard University Press. (in English)

Peirce, C. S. (1934b). Quale-Consciousness. In C. Hartshorne \& P. Weiss (Eds.), Collected Papers of Charles Sanders Peirce: Vol. V and VI: Pragmatism and Pragmaticism and Scientific Metaphysics (Vol. 6, pp. 150-154). Cambridge: The Belknap Press of Harvard University Press. (in English)

Peirce, C. S. (1966). Logic of 1873. In A. W. Burks (Ed.), Collected Papers of Charles Sanders Peirce: Vol. VII and VIII: Science and Philosophy and Reviews, Correspondence and Bibliography (Vol. 7, pp. 194-222). Cambridge: The Belknap Press of Harvard University Press. (in English)

Quine, W. V. (1951). Main Trends in Recent Philosophy: Two Dogmas of Empiricism. The Philosophical Review, 60(1), 20-43. doi: https://doi.org/10.2307/2181906 (in English)

Quine, W. V. O. (1960). Word and Object. The MIT Press. (in English)

Rorty, R. (1998). Truth and Progress: Philosophical Papers (Vol. 3). Cambridge University Press. (in English)

Schiller, F. C. S. (1907). Studies in humanism. London: Macmillan and Co. (in English)

Schiller, F. C. S. (1938). The Personalistic Implications of Humanism: II. Logic: A game, or an agent of value. The Personalist, 19(1), 16-31. (in English)

Snitko, D. Y. (2017). Will to truth in the philosophy of pragmatism. Anthropological Measurements of Philosophical Research, 12, 113-120. doi: https://doi.org/10.15802/ampr.v0i12.119138 (in Ukrainian)

Synytsia, A. S. (2017). Suchasna analitychna filosofiia: Vid prahmatyky movy do kontseptualizatsii svidomosti: Monohrafiia. Lviv: Ivan Franko National University of Lviv. (in Ukraininan)

\section{LIST OF REFERENCE LINKS}

Pragmatism and the European Traditions: Encounters with Analytic Philosophy and Phenomenology before the Great Divide / eds. M. Baghramian, S. Marchetti. - Routledge, 2018. - 306 p.

Bellucci, F. Peirce’s Speculative Grammar: Logic as Semiotics / F. Bellucci. - Routledge, 2017. - 400 p.

Boncompagni, A. Wittgenstein and Pragmatism / A. Boncompagni. - London : Palgrave Macmillan, 2016. - 311 p.

Brandom, R. Perspectives on Pragmatism: Classical, Recent, and Contemporary / R. Brandom. - Harvard University Press, 2011. -248 p.

Carroll, J. William James and 18th-Century Anthropology: Holism, Scepticism and the Doctrine of Experience / J. Carroll // History of the Human Sciences. - 2018. - Vol. 31, Iss. 3. - P. 3-20. doi: https://doi.org/ $10.1177 / 0952695118764060$

Dewey, J. Reconstruction in Philosophy / J. Dewey. - New York : Henry Holt and Company, 1920. - 224 p.

Dewey, J. Experience and Education / J. Dewey. - New York : Free Press, 2015. - 91 p.

Goldman, L. Dewey's Pragmatism from an Anthropological Point of View / L. Goldman // Transactions of the Charles S. Peirce Society. - 2012. - Vol. 48, Iss. 1. - P. 1-30. doi: https://doi.org/10.2979/trancharpeirsoc.48.1.1

James, W. The Principles of Psychology : in two volumes / W. James. - New York : Henry Holt and Company, 1890. - Vol. 1. - 704 p.

James, W. Some Problems of Philosophy: A Beginning of an Introduction to Philosophy / W. James. - London : Longmans, Green, 1911. - $237 \mathrm{p}$.

James, W. Pragmatism: A New Name for Some Old Ways of Thinking / W. James. - Cambridge University Press, 2014. - 308 p.

Misak, C. Pragmatism and Analytic Philosophy / C. Misak // The Oxford Handbook of The History of Analytic Philosophy / ed. M. Beaney. - 2015. - P. 1098-1117.

Peirce, C. S. The Doctrine of Chances / C. S. Peirce // The Popular Science Monthly. - 1878. - Vol. 12. P. 604-615.

Peirce, C. S. On Selecting Hypotheses / C. S. Peirce // Collected Papers of Charles Sanders Peirce. Vol. V and VI : Pragmatism and Pragmaticism and Scientific Metaphysics / eds. C. Hartshorne, P. Weiss. - Cambridge, 1934. - Vol. V. - P. 413-422. 
Peirce, C. S. Quale-Consciousness / C. S. Peirce // Collected Papers of Charles Sanders Peirce. Vol. V and VI : Pragmatism and Pragmaticism and Scientific Metaphysics / eds. C. Hartshorne, P. Weiss. - Cambridge, 1934. - Vol. VI. - P. 150-154.

Peirce, C. S. The Logic of 1873 / C. S. Peirce // Collected Papers of Charles Sanders Peirce. Vol. VII and VIII : Science and Philosophy and Reviews, Correspondence and Bibliography / ed. A. W. Burks. - Cambridge, 1966. - Vol. VII. - P. 194-222.

Quine, W. V. Main Trends in Recent Philosophy: Two Dogmas of Empiricism / W. V. Quine // The Philosophical Review. - 1951. - Vol. 60, No. 1. - P. 20-43. doi: https://doi.org/10.2307/2181906

Quine, W. V. O. Word and Object / W. V. O. Quine. - The MIT Press, 1960. - 294 p.

Rorty, R. Truth and Progress: Philosophical Papers / R. Rorty. - Cambridge University Press, 1998. - Vol. 3. 363 p.

Schiller, F. C. S. Studies in humanism / F. C. S. Schiller. - London : Macmillan and Co., 1907. - 492 p.

Schiller, F. C. S. The Personalistic Implications of Humanism: II. Logic: A game, or an agent of value / F. C. S. Schiller // The Personalist. - 1938. - Vol. 19, Iss. 1. - P. 16-31.

Снітько, Д. Ю. Воля до істини у філософії прагматизму / Д. Ю. Снітько // Антропологічні виміри філософських досліджень. - 2017. - Вип. 12. - С. 113-120. doi: https://doi.org/10.15802/ampr.v0i12.119138

Синиця, А. С. Сучасна аналітична філософія: від прагматики мови до концептуалізації свідомості : монографія / А. С. Синиця. - Львів : Львівський національний університет імені Івана Франка, 2017. $448 \mathrm{c}$.

\section{А. С. СИНИЦЯ ${ }^{1^{*}}$}

$1^{*}$ Львівський національний університет імені Івана Франка (Львів, Україна), ел. пошта andrii.synytsia.edu@gmail.com, ORCID 0000-0002-0983-7187

\section{АНТРОПОЛОГІЧНІ ВИМІРИ ПРАГМАТИЗМУ І ПЕРСПЕКТИВИ СОЦІОГУМАНІТАРНОЇ РЕДЕСКРИПЦІї АНАЛІТИЧНОЇ МЕТОДОЛОГІї}

Мета. Дослідити специфіку антропологічної проблематики в прагматизмі з огляду на їі можливості бути джерелом поступу аналітичної філософії в соціогуманітарній площині. Теоретичний базис дослідження визначен працями представників класичного прагматизму (Ч. С. Пірса, В. Джеймса, Дж. Дьюї, Ф. Шіллера), неопрагматизму (В. В. О. Куайна), постпрагматизму (Р. Рорті) й аналітичного прагматизму (Р. Брендома). Саме їхній творчий доробок дає чітке уявлення про вагоме місце антропологічних пошуків у теорії прагматизму. Наукова новизна. Доведено, що антропоцентричні ідеї прагматичної методології доцільно аналізувати в єдності їі логічних, епістемологічних і метафізичних начал. Встановлено, що саме завдяки інтересу до людської особистості світоглядно-соціальні основи теорії прагматизму можна визначити як плюралістичні. Виявлено, що, конкретизуючи стратегії пізнання людського буття в термінах на кшталт досвіду чи самості, й розвиваючи практичні способи обгрунтування істинності знань, теоретикометодологічні пошуки прагматизму можуть бути ефективними у процесі формування соціогуманітарних концепцій аналітичної філософії. Висновки. Теорія прагматизму критично ставиться до знеособленого, формального мислення, яке не може бути дієвим засобом пізнання. Мислення має соціальне підгрунтя і $є$ наскрізь особистісним. Обгрунтовуючи його залежність від соціокультурного середовища й внутрішніх інтенцій суб'єкта, логічна теорія не просто оперуватиме символами на синтаксичному чи семантичному рівні, а й враховуватиме прагматичний аспект мови. Особливої ваги набуває антропологічна проблематика і в теорії пізнання, осердям якої є поняття прагматичної віри, що уможливлює істинність і релігійних переконань, адже підгрунтя теорії істини детерміноване принципом гуманізму, а істина витлумачена як ціннісний орієнтир. Оскільки пізнання зовнішнього світу - це віднайдення схожості з нами, то й метафізичні основи буття, згідно з прагматизмом, персоніфіковані, а методологія - визначена в антропоморфних термінах. Застосовуючи iï, дослідження людського буття конкретизоване у процесі аналізу психологічних і соціокультурних вимірів концептів досвіду й самості. Спроби осягнути природу людського буття в прагматизмі емпірично обгрунтовані. Апелювання до науки, плюралізм методології, пошук соціокультурних 
передумов мислення й відповідних мовних форм вираження людського досвіду є тим здобутком прагматизму, який виступає підгрунтям соціогуманітарної редескрипції аналітичної методології.

Ключові слова: антропологія; антропоморфізм; принцип гуманізму; досвід; самість; прагматизм; аналітична філософія

\author{
А. С. СИНИЦА ${ }^{1 *}$ \\ ${ }^{1 *}$ Львовский национальный университет имени Ивана Франко (Львов, Украина), эл. почта andrii.synytsia.edu@gmail.com, \\ ORCID 0000-0002-0983-7187
}

\title{
АНТРОПОЛОГИЧЕСКИЕ ИЗМЕРЕНИЯ ПРАГМАТИЗМА И ПЕРСПЕКТИВЫ СОЦИОГУМАНИТАРНОЙ РЕДЕСКРИПЦИИ АНАЛИТИЧЕСКОЙ МЕТОДОЛОГИИ
}

Цель. Исследовать специфику антропологической проблематики в прагматизме, учитывая ее возможности быть источником развития аналитической философии в социогуманитарной плоскости. Теоретический базис исследования определен трудами представителей классического прагматизма (Ч. С. Пирса, В. Джеймса, Дж. Дьюи, Ф. Шиллера), неопрагматизма (В. В. О. Куайна), постпрагматизма (Р. Рорти) и аналитического прагматизма (Р. Брендома). Именно их творчество дает представление о весомом месте антропологических поисков в теории прагматизма. Научная новизна. На основании анализа логических, эпистемологических и метафизических идей, сформулированных представителями прагматизма, доказано, что применяемая ими методология является антропоцентрической. Установлено, что именно благодаря интересу к человеческой личности мировоззренчески-социальные основы теории прагматизма можно определить как плюралистические. Выявлено, что конкретизируя стратегии познания человеческого бытия, к примеру, в терминах опыта или самости, и развивая практические способы обоснования истинности знаний, теоретикометодологические поиски прагматизма могут быть эффективными в процессе формирования социогуманитарных концепций аналитической философии. Выводы. Теория прагматизма критически относится к обезличенному, формальному мышлению, которое не может быть действенным средством познания. Мышление имеет социальную подоплеку, оно насквозь личностное. Обосновывая его зависимость от социокультурной среды и внутренних интенций субъекта, логическая теория будет не только оперировать символами на синтаксическом или семантическом уровне, но и учитывать прагматический аспект языка. Особое значение приобретает антропологическая проблематика и в теории познания, ядром которой является понятие прагматической веры, что делает возможным истинными и религиозные убеждения, ведь основания теории истины детерминированно принципом гуманизма, а истина проинтерпретированна как ценностный ориентир. Поскольку познание внешнего мира - это нахождение сходства с нами, то и метафизические основания бытия, согласно прагматизму, персонифицированные, а методология - определена в антропоморфных терминах. Применяя ее, исследования человеческого бытия конкретизировано в процессе анализа психологических и социокультурных измерений концептов опыта или самости. Попытки понять природу человеческого бытия в прагматизме эмпирически обоснованы. Апеллирование к науке, плюрализм методологии, поиск социокультурных предпосылок мышления и соответствующих языковых форм выражения человеческого опыта является тем достижением прагматизма, которое выступает основой социогуманитарной редескрипции аналитической методологии.

Ключевые слова: антропология; антропоморфизм; принцип гуманизма; опыт; самость; прагматизм; аналитическая философия

Received: 25.06.2019

Accepted: 15.11.2019 